\title{
Pengembangan Inventori Resiliensi Mahasiswa Bimbingan dan Konseling Islam Institut Agama Islam Negeri Tulungagung
}

\author{
Muhammad Sholihuddin Zuhdi \\ Institut Agama Islam Negeri Tulungagung \\ zuhdi.bk@gmail.com
}

\begin{abstract}
This article focuses on the study room of the student of Islamic Guidance and Counseling Students IAIN Tulungagung. The approach used in this study is a quantitative approach, using descriptive analysis methods. Adolescence is a period of storm and stress, a period in which teenagers are turbulent and contain conflicts and mood swings. These developments will enter early adulthood, which requires major changes in thinking and acting, from which independence is the most important thing to become the basis for further developments. Every student has different ways to deal with existing stressors. Individuals who are able to survive certainly have an attitude in dealing with stress so that each student must be able to become resilient. Resilience is very important to develop in students, so an instrument is also needed to determine the level of student resilience, because so far the counselor in particular does not yet have a measure of resilience as the first step in developing student resilience. The results of the research are: 1). Inventory Resilience is very easy to use because there are clear instructions in the process, 2). Based on the assessment of content experts from inventory Resilience developed according to the conditions of Islamic Guidance and Counseling Students IAIN Tulungagung, 3). Based on the small group test shows that inventory resilience is well received by students, 4). Inventory Resilience has limitations and weaknesses that still need further improvement and development.
\end{abstract}

Keywords: Inventory, Resilience, Students

\begin{abstract}
Abstrak
Artikel ini dititik beratkan pada ruang telaah mahasiswa bimbingan dan konseling IAIN Tulungagung. Pendekatan yang digunakan dalam penelitian ini adalah pendekatan kuantitatif, dengan menggunakan metode deskriptif analisis. Masa remaja merupakan
\end{abstract}


masa storm and stress, masa di mana remaja sedang bergejolak dan berisi konflik serta perubahan suasana hati. Perkembangan tersebut akan memasuki masa dewasa awal, yang menuntut perubahan besar dalam berfikir dan bertindak, dari hal tersebut kemandirian merupakan hal yang paling utama menjadi dasar dalam perkembangan selanjutnya. Setiap mahasiswa memiliki cara yang berbeda untuk menyikapi stresor yang ada. Individu yang mampu bertahan tentunya mempunyai sikap dalam menghadapi stress sehingga setiap mahasiswa harus bisa menjadi resilien. Resiliensi sangat penting untuk dikembangkan dalam diri mahasiswa, maka perlu pula disusun sebuah instrument untuk mengetahui tingkat resiliensi mahasiswa, karena selama ini konselor khususnya belum mempunyai alat ukur resiliensi sebagai langkah awal pengembagan resiliensi mahasiswa untuk itu perlu dikembangkan instrumen berbentuk inventori mengenai resiliensi. Hasil penelitannya adalah: 1). Inventori Resiliensi sangat mudah untuk digunakan karena terdapat petunjuk yang jelas dalam pengerjaanya, 2). Berdasarkan penilaian ahli isi dari inventori Resiliensi yang dikembangkan telah sesuai dengan kondisi Mahasiswa Bimbingan dan Konseling Islam IAIN Tulungagung, 3). Berdasarkan uji kelompok kecil menunjukan bahwa inventori Resiliensi diterima baik oleh mahasiswa, 4). Inventori Resiliensi memiliki keterbatasan dan kelemahan yang masih memerlukan perbaikan dan pengembangan selanjutnya.

Kata Kunci: Inventori, Resiliensi, Mahasiswa

\section{Pendahuluan}

Masa remaja merupakanmasa transisidalam rentang kehidupan manusia, menghubungkan masa kanak-kanak dan dewasa. Seperti dalam perkembangan selama masa kanak-kanak, faktor genetik atau biologis dan lingkungan atau sosial mempengaruhi perkembangan remaja. ${ }^{1}$ Jika dibandingkan masa kanakkanak, masa remaja lebih berpengalaman dalam berinteraksi dengan orang tua, teman, dan guru. Namun masa remaja sedang menghadapi perubahan biologis, pengalaman baru serta tugas-tugas perkembangan baru. Selain itu masa remaja adalah dimana hubungan dengan teman sebaya menjadi lebih intim jika dibandingkan dengan orang tua dan pola fikir remaja menjadi lebih abstrak dan idealistik.

Masa remaja merupakan masa storm and stress, masa di mana remaja sedang bergejolak dan berisikonflikserta perubahan suasana hati. Tugas

${ }^{1}$ John. W. Santrock, Life-span development 13th edition, (New York : McGraw-Hill, 2010), h. 352 
perkembangan remaja yang akan memasuki masa dewasa awal, menuntut perubahan besar dalam berfikir dan bertindak, dari hal tersebut kemandirian merupakan hal yang paling utama menjadi dasar dalam perkembangan selanjutnya. Untuk mencapai kemandirian, banyak hambatan umum yang ditemui pada masa remaja, diantaranya terlalu lama diperlakukan seperti anakanak, perubahan peran dari anak-anak menjadi dewasa, ketergantungan kepada orang lain terutama pada orang tua yang terlalu lama dan terlambat dalam kematangan sehingga kurang mampu menguasai tugas-tugas perkembangan. Hambatan-hambatan tersebut mengakibatkan ketidakmatangan remaja yang dapat menimbulkan stres dan ketidakmampuan remaja dalam menyesuaikan diri yang menimbulkan pikiran dan perasaan yang mudah menyerah.

Stress menurut Galinsky, merupakan tahap emergency utama dari hambatan dan tantangan yang memiliki dampak-dampak pada kemampuannya untuk mengingat, memperhatikan, mengontrol diri dan meningkatkan emosi negatif. ${ }^{2}$ Hambatan-hambatan remaja tersebut banyak ditemukan pada masa remaja akhir khususnya pada Mahasiswa. Pendidikan di Perguruan Tinggi merupakan pendidikan yang dipersiapkan untuk memenuhi kebutuhan-kebuhan di masyarakatsehingga lulusannya dipersiapkan untuk terjun ke dunia kerja bahkan membuka lapangan usaha baru. Perguruan Tinggi dituntut untuk menguasai berbagai kemampuan atau kompetensi, baik yang berhubungan dengan mata kuliah umum maupun mata pelajaran keahlian atau produktif yang mengarah pada perkembangan karir mereka. Sehingga, mahasiswa harus mampu beradaptasi terhadap bidang keahlian mereka dan dunia baru yang akan digeluti setelah mereka lulus yakni dunia kerja.

Pada realitanya tuntutan dan harapan untuk mencapai tujuan bagi mahasiswa sering mendapatkan hambatan sehingga tidak semua mahasiswa dapat memenuhi tuntutan tersebut., hambatan tersebut berkaitan dengan berbagai faktor, khususnya di bidang karir misalnya proses adaptasi pada dunia kerja, pembudayaan etos kerja, problematika dunia kerja, membangun jiwa enterpreneur, melihat peluang, dan membuat perencanaan usaha yang merupakan soft skill yang kurang diberikan pada masa sekolah, sehingga mereka harus belajar secara mandiri. Untuk mencapai kesuksesan terutama di dunia kerja, diperlukan sebuah ketrampilan untuk mengatasi hambatan atau tantangan dan untuk beradaptasi dengan segala kesulitan hidup, agar mahasiswa nantinya dapat mengembangkan diri secara optimal di berbagai aspek kehidupannya. Dukungan sosial mahasiswa bidik misi melalui mediasi efikasi diri menghasilkan

\footnotetext{
${ }^{2}$ Ellen. Galinsky, Mind In The Making, ( New York: Harper Collins Publisher, 2010), h.
} 
resiliensi yang lebih tinggi dibandingkan dengan hubungan dukungan sosial masiswa bidik misi dengan resiliensi tanpa mediasi efikasi diri. ${ }^{3}$

Setiap mahasiswa memiliki cara yang berbeda untuk menyikapi stresor yang ada. Individu yang mampu bertahan tentunya mempunyai sikap dalam menghadapi stress sehingga setiap mahasiswa harus bisa menjadi resilien, yaitu dapat beradaptasi, mampu untuk bertahan, dan bangkit. individu yang resiliensi akan memiliki stress yang lebih rendah. Sebaliknya, individu yang menunjukkan angka stress yang tinggi adalah individu yang cenderung kurang resilien. ${ }^{4}$

Kemampuan untuk mengatasi dan beradaptasi terhadap kejadian yang berat atau masalah yang terjadi dalam kehidupan disebut resiliensi.$^{5}$ Resiliensi merupakan suatu konsep yang menarik karena memberikan beberapa jenis jawaban mengapa satu orang hancur ketika menghadapi masa sulit dan sebaliknya seseorang menjadikan hal tersebut sebagai suatu keuntunganbagi mereka. Resiliensi menurut Persaud (dalam Neenan) adalah fondasi darikesehatan mentalyang positif. Resiliensi merupakan kemampuan kognitif dan sosioemosional. ${ }^{6}$ Secara implisit Piaget (dalam Greff, 2005) menulis tentang nature intelligence yang mendefinisikan resiliensi ketika ia mengatakan bahwa "hal tersebut mengetahui apa yang harus dilakukan ketika anda tidak tahu apa yang harus dilakukan". ${ }^{7}$ Dalam hal tersebut resiliensi berarti memiliki ketahanan dalam kondisi yang sulit. Resiliensi bukan hanya kemampuan untuk bertahan dalam kesulitan, namun juga menyembuhkan atau dapat mencari solusi.

Dari hasil wawancara yang dilakukan 5 (lima) mahasiswa Bimbingan dan Konseling tingkat akhir ditemukan rata-rata mereka menyatakan kebingungan apa yang akan dilakukan ketika nanti setelah lulus dari bangku kuliah, dan mereka belum punya rencana yang matang karena masih merasa takut tidak diterima kerja bahkan mereka tidak punya rencana untuk membuka lapangan pekerjaan tertentu dengan alasan takut kecewa dengan hasilnya, merasa sulit menonjolkan keahlianya, takut dengan pesaing-pesaingnya.

Selain itu dilakukan wawancara dengan salah seorang direksi perusahaan besar di Kota Blitar diceritakan salah satu manajernya mengalami stres kemudian

3 Mufidah, A. C. (2018). Hubungan antara dukungan sosial dengan resiliensi yang dimoderatori oleh locus of control pada mahasiswa bidikmisi. PSIKODIMENSLA, 16(2), 121130.

4 Septiani, T., \& Fitria, N. (2016). Hubungan antara resiliensi dengan stres pada mahasiswa Sekolah Tinggi Kedinasan. Jurnal penelitian psikologi, 7(2), 59-76.

${ }^{5}$ Reivich, Karen \& Andrew, Shatte, The Recilience Factor, (New York: Broadway Books, 2012), h. 26

6 Michael Neenan,, Developing Resilience a Cognitive Behavioral Approach, (New York : Routledge, 2009), h. 3

7 Annie Greeff, Resilience: Social Skills for Effective Learning vol.2, (USA: Crown house publishing company, 2005), h. 10 
berlanjut sampai depresi bahkan sampai meninggal dunia. Hal tersebut disebabkan karena adanya ketidak mampuan dirinya dalam beradaptasi dengan tuntutan pekerjaanya, padahal menurut direksi tersebut manajer-manajer lainya melakukan pekerjaan tersebut hal yang biasa tanpa ada beban yang berat apalagi sampai berdampak seperti itu.

Berdasarkan pernyataan dari para ahli dan kasus-kasus tersebut menurut hemat penulis sangat penting resiliensi untuk dikembangkan dalam diri mahasiswa, maka perlu pula disusun sebuah instrument untuk mengetahui tingkat resiliensi mahasiswa, karena selama ini konselor khususnya belum mempunyai alat ukur resiliensi sebagai langkah awal pengembagan resiliensi mahasiswa untuk itu perlu dikembangkan instrumen berbentuk inventori mengenai resiliensi . Pengembangan inventori ini sangat perlu sebagai langkah awal untuk mendapatkan gambaran mengenai tingkat resiliensi mahasiswa yang pada selanjutnya untuk langkah awal mengembangkan resiliensi, manfaat selanjutnya adalah memberikan kontribusi penting bagi konselor untuk mendiagnosa perilaku negatif yang diakibatkan oleh rendahnya tingkat resiliensi mahasiswa dan memberikan layanan bantuan yang tepat bagi para mahasiswa tersebut agar dapat berkembang secara optimal.

Metode yang digunakan dalam penulisan penelitian ini adalah Model pengembangan dalam penelitian ini menggunakan model pengembangan prosedural, yaitu model pengembangan prosedural yang bersifat deskriptif. Model pengembangan prosedural menggariskan langkah-langkah yang harus diikuti untuk menghasilkan produk. Penelitian ini mengadaptasi model penelitian pengembangan yang dikembangkan oleh Borg dan Gall karena model ini dapat digunakan untuk menghasilkan suatu produk, ${ }^{8}$ dalam hal ini adalah inventori.

Prosedur pengembangan inventori Resiliensi bagi mahasiswa Bimbingan dan Konseling Islam ini merupakan adaptasi dari teori Borg dan Gall. ${ }^{9}$ Desain uji coba yang digunakan oleh peneliti adalah desain deskriptif. Rangkaian desain uji coba adalah sebagai berikut:

1. Uji ahli Bimbingan dan Konseling ini penting dilakukan untuk menilai relevansi antara teori Resiliensi, variabel, sub-variabel, indikator, deskriptor, dan item-item pernyataan yang dikembangkan. Selain itu kegiatan ini penting bagi peneliti untuk mendapatkan masukan-masukan mengenai pemanfaatan inventori Resiliensi sesuai dengan disiplin ilmu dalam profesi Bimbingan dan Konseling dan masukan mengenai kesesuaian penggunaan bahasa dalam item-item pernyataan yang dikembangkan.

\footnotetext{
${ }^{8}$ Borg, W. R. and Gall, M. D, Education Research.Longman Inc. 95 Street, White Plains, 1983.

${ }^{9}$ Borg, W. R. and Gall, M. D, Education Research.Longman Inc. 95 Street, White Plains, 1983.
} 
2. Uji coba produk tahap awal ini dilakukan untuk menilai apakah produk telah memenuhi syarat validitas dan reliabilitas dari setiap item. Uji coba produk tahap awal ini dilakukan setelah revisi dari ahli Bimbingan Konseling.

3. Uji ahli bahasa ini dilakukan untuk menilai apakah penampilan dari inventori Resiliensi ini telah meyakinkan dan memberikan kesan mampu mengungkapkan apa yang hendak diukur. Melalui uji ahli bahasa ini, peneliti akan memperoleh masukan, saran, dan kritik untuk perbaikan produk.

4. Uji coba calon pengguna produk bertujuan untuk melakukan uji keterbacaan inventori Resiliensi oleh konselor. Setelah dilakukan uji coba calon pengguna produk, maka dilakukan revisi untuk menghasilkan produk yang akan diujicobakan pada kelompok kecil.

5. Uji coba kelompok kecil ini bertujuan untuk melakukan uji keterbacaan inventori Resiliensi serta mengetahui tingkat Resiliensi mahasiswa. Setelah dilakukan uji kelompok kecil ini dilakukan revisi tahap akhir untuk menghasilkan produk akhir.

Subjek pengembangan adalah ahli Bimbingan dan Konseling, ahli bahasa, mahasiswa uji coba tahap awal, konselor, dan mahasiswa uji kelompok kecil. Uji ahli Bimbingan Konseling dilakukan oleh dosen Bimbingan dan konseling yang merupakan seorang ahli di bidang isi produk dan penggunaan bahasa dari item-item pernyataan yang dikembangkan. Uji ahli Bimbingan Konseling ini dilakukan oleh Desika Nanda N, M.Pd. Uji bahasa dilakukan oleh dosen bahasa yang merupakan seorang ahli di bidang bahasa. Uji ahli bahasa ini dilakukan olehNingrum, M.Pd, dosen jurusan Bahasa Indonesia. Mahasiswa subjek coba tahap awal merupakan mahasiswa Bimbingan dan Konseling Islam yang terdiri atas empat kelas, sedangkan subjek coba calon pengguna produk dan subjek coba uji kelompok kecil merupakan 20 mahasiswa Bimbingan dan Konseling Islam.

Populasi dalam penelitian ini adalah mahasiswa Bimbingan dan Konseling Islam IAIN Tulungagung, sedangkan penentuan sampel mahasiswa subjek coba tahap awal dan uji kelompok kecil dilakukan dengan menggunakan teknik cluster random sampling. Hal ini karena pemilihan sampel dilakukan secara acak, namun pemilihan sampel tidak berdasarkan mahasiswa secara individual melainkan mahasiswa secara kelompok. Jenis data berdasarkan hasil uji coba diperoleh data kualitatif dan kuantitatif. Data kualitatif diperoleh berdasarkan: (1) masukan, tanggapan, dan saran dari ahli bimbingan dan konseling, (2) masukan, tanggapan, dan saran dari ahli bahasa , (3) masukan, tanggapan, dan saran dari konselor subjek coba calon pengguna produk, dan (4) masukan, tanggapan, dan saran mahasiswa subjek uji coba kelompok kecil.

\section{Hasil dan Pembahasan}

\section{Pengertian Resiliensi}


Resiliensi pertama kali dikenalkan oleh Block dalam Klohnen (1996) dengan nama ego-resilience, yang berarti suatu kemampuan umum yang melibatkan kemampuan penyesuaian diri tinggi dan luwes saat dihadapkan tekanan internal maupun eksternal. Secara spesifik, ego-resilience adalah: “... a personality resource that allows individual to modify their characteristic level and habitual mode of expression of egocontrol as the most adaptively encounter, function in and shape their immediate and long term environmental context (Block dalam Klohnen). ${ }^{10} \mathrm{Hal}$ tersebut berarti bahwa ego resiliensi adalah satu sumber kepribadian yang memiliki fungsi membentuk konteks lingkungan jangka pendek maupun jangka panjang, di mana sumber daya tersebut memungkinkan individu dalam memodifikasi tingkat karakter dan cara dalam mengekspresikan pengendalian ego yang biasa mereka lakukan.

Ada beberapa yang menyatakan bahwa istilah resiliensi pertama kali digunakan dalam ekologi, di mana ketahanan mengarah pada kemampuan ekosistem untuk bangkit kembali setelah adanya guncangan besar. ${ }^{11}$ Dalam perjalanannya, terminologi resiliensi mengalami perluasan dalam hal pemaknaan. Diawali dengan penelitian Rutter \& Garmezy (dalam Klohnen, 2010), mengenai anak-anak yang dapat bertahan dalam situasi penuh tekanan. ${ }^{12}$ Dua peneliti tersebut menggunakan istilah resiliensi sebagai descriptive labels yang digunakan untuk menggambarkan anak-anak yang mampu berfungsi dengan baik walaupun mereka hidup dalam lingkungan buruk dan penuh tekanan.

Menurut Grotberg resiliensi adalah kemampuan seseorang dalam menilai, mengatasi, serta meningkatkan diri ataupun mengubah dirinya dari keterpurukan atau kesengsaraan dalam hidupnya. ${ }^{13}$ Menurut Reich, dll, resilience is best defined asan outcome of successful adaptation to adversity, atau resiliensi merupakan hasil adaptasi yang sukses dari kesulitan, sehingga resiliensi manusia mengarah pada proses atau pola adaptasi yang positif dan pembangunan dalam konteks ancaman yang signifikan untuk kehidupan atau keberfungsian individu itu sendiri. ${ }^{14}$ Hal senada dinyatakan oleh Reivich dan Shatte, bahwa resiliensi merupakan kemampuan dalam mengatasi dan beradaptasi terhadap kejadian

${ }^{10}$ Klohnen, E.C. 2010. Conseptual Analysis and Measurement of The Construct of Ego Resilience. Journal of Personality and Social Psychology, Volume. 70 No 5, p 1067-1079.

11 Mohaupt, Sarah. 2018. Review Article: Resilience and Social Exclusion. Journal of Social Policy \& Society 8:1, 63-71

12 Klohnen, E.C. 2010. Conseptual Analysis and Measurement of The Construct of Ego Resilience. Journal of Personality and Social Psychology, Volume. 70 No 5, p 1067-1079.

${ }^{13}$ Henderson Grotberg, Tapping Your Inner Strength How To Find The Recilience To Deal With Anything, (Canada: New Harbinger Publications, Inc, 1999), h. 3

${ }^{14}$ John. W. Reich, et.al, Handbook Of Adult Resilience, (New York: A Division of Guilford Publications, 2003), h. 4 
yang berat atau masalah yang terjadi pada kehidupan. ${ }^{15}$ Bertahan pada keadaan tertekan, dan bahkan berhadapan dengan kesulitan (adversity) atau trauma yang dialami dalam kehidupannya. Penelitian ilmiah yang telah dilakukan lebih dari 50 tahun membuktikan bahwa resiliensi merupakan kunci dari kesuksesan kerja dan kepuasan hidup.

Selanjutnya Siebert (2005: 16) dalam bukunya The Resiliency Advantage menjelaskan bahwa resiliensi merupakan kemampuan untuk mengatasi dengan baik perubahan hidup pada level yang tinggi, menjaga kesehatan di bawah kondisi penuh tekanan, bangkit dari keterpurukan, mengatasi kemalangan, mengubah cara hidup saat cara yang lama tidak sesuai lagi dengan kondisi yang ada, dan menghadapi permasalahan tanpa melakukan kekerasan.

Definisi yang sangat menekankan dua elemen penting untuk mendefinisikan resiliensi (Luthar dan Zelazo, 2003; Lutharet al, 2000;. Mastenet al, 1990;. Rutter, 1987; Werner dan Smith, 1988), Pertama, perspektif masukan: eksposur terhadap risiko dan keadaan yang merugikan, yang bervariasi dari sedang hingga risiko lingkungan yang ekstrim. Risiko dapat dikonseptualisasikansebagai berikut: digunakan dalammemprediksikerentanan terhadap berbagai hasil kehidupan negatif termasuk kegagalan sekolah dan atau putus sekolah, penyalahgunaan narkoba, hubungan gagal, kenakalan/kegiatan kriminal, pengangguran, kesehatan yang buruk dan kematian dini (Howard etal., 1999). Elemen kedua dari definisi ketahanan dalam hal perspektif hasil, mempelajari apakah mekanisme koping menyebabkan hasil dalam atau di atas kisaran yang diharapkan.

Dari beberapa pengertian resiliensi yang telah dijelaskan di atas dapat disimpulkan bahwa resiliensi merupakan kemampuan seseorang untuk bertahan dalam keadaan sulit di hidupnya, berusaha belajar dan beradaptasi dengan keadaan tersebut serta bangkit dari keterpurukan untuk menjadi lebih baik. Hal penting yang dapat dicatat disini bahwa resiliensi tidak pernah diukur secara langsung, tetapi disimpulkan dari unsur-unsur yang mendefinisikan seperti risiko dan adaptasi. Suatu misal hasil positif dari adaptasi dapat mengurangi kecemasan anak di bawah stres yang disebabkan oleh perang atau bencana alam.

\section{Aspek-aspek resiliensi}

Reivich dan Shatte, ${ }^{16}$ menjelaskan tujuh kemampuan yang membentuk resiliensi, yaitu sebagai berikut:

a. Emotion Regulation

${ }^{15}$ Reivich, Karen \& Andrew, Shatte, The Recilience Factor, (New York: Broadway Books, 2012), h. 26

${ }^{16}$ Reivich, Karen \& Andrew, Shatte, The Recilience Factor, (New York: Broadway Books, 2012), h. 34 
Regulasi emosi merupakan kemampuan untuk tetap tenang di bawah kondisi yang menekan. Dari hasil penelitian menunjukkan bahwa orang yang kurang memiliki kemampuan dalam mengatur emosi mengalami kesulitan untuk membangun dan menjaga hubungan dengan orang lain. Hal tersebut bisa disebabkan oleh berbagai faktor, di antara alasan yang sederhana adalah tidak ada orang yang mau menghabiskan waktu dengan orang yang marah, merengut, cemas, khawatir serta gelisah setiap saat. Seseorang yang merasa emosi akan cenderung berpengaruh terhadap orang lain. Semakin kita terasosiasi dengan kemarahan maka kita akan semakin menjadi seorang yang pemarah.

Tidak semua emosi yang dirasakan oleh individu harus dikontrol. Tidak semua emosi marah, sedih, gelisah dan rasa bersalah harus diminimalisir. Hal ini dikarenakan mengekspresikan emosi yang kita rasakan baik emosi positif maupun negatif adalah hal yang konstruksif dan sehat, bahkan kemampuan untuk mengekspresikan emosi secara tepat merupakan bagian dari resiliensi .

Reivich dan Shatte juga menjelaskan dua buah keterampilan yang dapat memudahkan individu dalam melakukan regulasi emosi, yaitu tenang (calming) dan fokus (focusing). Dua buah keterampilan ini akan membantu individu untuk mengontrol emosi yang tidak terkendali, menjaga fokus pikiran individu pada saat banyak hal-hal yang mengganggu, serta mengurangi stres yang dialami oleh individu.

b. Impulse Control

Pada tahun 1970, Goleman (dalam Reivich \& Shatte, 2002), penulis dari Emotional Intelligence, melakukan penelitian yang berkaitan dengan kemampuan individu dalam pengendalian impuls. Penelitian dilakukan kepada 7 orang anak kecil yang berusia sekitar 7 tahun. Dalam penelitian tersebut masingmasing anak ditempatkan pada ruangan yang berbeda. Pada masing-masing ruangan telah terdapat peneliti yang menemani anak-anak tersebut. Masingmasing peneliti telah diatur untuk meninggalkan ruangan dalam beberapa selang waktu. Sebelum peneliti pergi, sebuah marshmallow diberikan kepada masingmasing anak untuk dimakan oleh mereka. Akan tetapi peneliti juga menawarkan jika mereka dapat menahan untuk tidak memakan marshmallow sampai peneliti kembali ke ruangan, maka mereka akan memperoleh satu buah marshmallow lagi. ${ }^{17}$

Setelah sepuluh tahun, keberadaan anak-anak tersebut telah dilacak oleh peneliti dan terbukti bahwa anak-anak yang dapat menahan untuk tidak memakan Marshmallow, kemampuan akademis dan sosialisasi yang dimiliki lebih baik dibandingkan dengan anak-anak yang sebaliknya.

${ }^{17}$ Reivich, Karen \& Andrew, Shatte, The Recilience Factor, (New York: Broadway Books, 2012), h. 37-39 
Pengendalian impuls merupakan kemampuan individu dalam mengendalikan keinginan, dorongan, kesukaan, serta tekanan yang muncul dari dalam diri individu yang memiliki kemampuan pengendalian impuls rendah, cepat mengalami perubahan emosi yang pada ujungnya mengendalikan pikiran dan perilaku mereka. Mereka menampilkan perilaku mudah marah, kehilangan kesabaran, impulsif, dan berlaku agresif. Perilaku yang ditampakkan ini tentu akan membuat orang di sekitarnya merasa kurang nyaman sehingga berakibat pada hubungan sosial individu dengan orang lain yang buruk.

Impulsivitas dapat dikendalikan oleh individu dengan mencegah terjadinya kesalahan pemikiran, sehingga dapat memberikan respon yang tepat pada suatu permasalahn yang ada. Dapat dilakukan pencegahan dengan menguji keyakinan individu dan mengevaluasi kebermanfaatan terhadap pemecahan masalah. Pertanyaan-pertanyaan yang bersifat rasional dapat diutarakan oleh individu yang ditujukan kepada dirinya sendiri, seperti 'apakah penyimpulan terhadap masalah yang saya hadapi berdasarkan fakta atau hanya menebak?', 'apakah saya sudah melihat permasalahan secara keseluruhan?', 'apakah manfaat dari semua ini?', dan lain-lain.

Kemampuan individu dalam mengendalikan impuls sangat berkaitan dengan kemampuan regulasi emosi yang dimilikinya. Seorang individu yang memiliki skor Resilience Quotient tinggi pada faktor regulasi emosi akan cenderung memiliki skor Resilience Quotient pada faktor pengendalian impuls.

c. Optimism

Individu yang resilien merupakan individu yang optimis, optimisme adalah pada saat kita melihat bahwa masa depan kita cemerlang. ${ }^{18}$ Seorang individu yang memiliki optimisme menandakan bahwa individu tersebut percaya jikalau dirinya memiliki kemampuan untuk mengatasi kemalangan yang mungkin akan terjadi di masa depan. Hal ini juga merefleksikan self-efficacy yang dimiliki oleh seseorang, yaitu individu yang percaya bahwa ia mampu menyelesaikan suatu permasalahan dan mengendalikan hidupnya. Optimisme akan menjadi hal yang sangat bermanfaat untuk individu apabila diikuti dengan self-efficacy, hal ini dikarenakan dengan optimisme yang ada seorang individu akan terus didorong untuk memecahkan permasalahan dan akan terus bekerja keras demi kondisi yang lebih baik.

Sudah pasti optimisme yang dimaksud adalah optimisme realistis (realistic optimism), yaitu kepercayaan akan terwujudnya masa depan yang lebih baik dengan diiringi segala usaha dalam mewujudkan hal tersebut. Berbeda dengan unrealistic optimism dimana kepercayaan akan masa depan yang cerah tidak diikuti dengan usaha yang signifikan dalam mewujudkannya. Perpaduan

${ }^{18}$ Reivich, Karen \& Andrew, Shatte, The Recilience Factor, (New York: Broadway Books, 2012), h. 29 
antara optimisme yang realistis dan self-efficacy merupakan kunci resiliensi dan kesuksesan.

d. Causal Analysis

Causal analysis merujuk pada kemampuan individu untuk mengidentifikasikan secara akurat penyebab dari permasalahan yang dihadapi mereka. Ketidakmampuan seorang individu dalam mengidentifikasikan penyebab dari permasalahan yang mereka hadapi secara tepat, akan berbuat kesalahan yang sama secara terus menerus.

Seligman (dalam Reivich \& Shatte) mengidentifikasi bahwa gaya berpikir explanatory yang erat hubungannya terhadap kemampuan causal analysis yang dimiliki individu. Gaya berpikir explanatory terbagi dalam tiga dimensi yaitu: personal (saya-bukan saya), permanen (selalu-tidak selalu), dan pervasive (semua-tidak ssemua). ${ }^{19}$

Individu dengan gaya berpikir "Saya-Selalu-Semua" merefleksikan keyakinan bahwa penyebab permasalahan berasal dari individu tersebut (Saya), hal ini selalu terjadi dan permasalahan yang ada tidak dapat diubah (Selalu), serta permasalahan yang ada akan mempengaruhi seluruh aspek hidupnya (Semua). Sementara individu yang memiliki gaya berpikir "Bukan Saya-Tidak Selalu-Tidak semua" meyakini bahwa permasahalan yang terjadi disebabkan oleh orang lain (Bukan Saya), dimana kondisi tersebut masih memungkinkan untuk diubah (Tidak Selalu) dan permasalahan yang ada tidak akan mempengaruhi sebagian besar hidupnya (Tidak semua).

Explanatory adalah gaya pikir yangmemegang peranan penting dalam suatu konsep resiliensi. Individu yang fokus dalam "Selalu-Semua" tidak dapat melihat jalan keluar dari permasalahan yang dihadapi oleh mereka. Sebaliknya "Tidak selalu-Tidak semua" yang cenderung digunakan individu dalam gaya berpikir dapat dirumuskan solusi serta tindakan yang akan dilakukan mereka dalam menyelesaikan permasalahan. ${ }^{20}$

Fleksibelitas kognitif yang dimiliki individu termasuk dalam Individu yang resilien. Semua faktor yang menyebabkan kemalangan yang menimpa mereka dapat diidentifikasikannya, tanpa terkecoh dalam salah satu gaya berpikir explanatory. Tidak diabaikannya oleh merekat mengenai faktor permanen maupun pervasif. Tidak menyalahkan orang lain karena kesalahan yang diperbuat mereka demi menjaga self-esteem atau membebaskannya mereka dari rasa bersalah adalah merupakan individu yang resilien. Mereka tidak begitu fokus dalam faktor-faktor yang ada di luar kendali mereka, sebaliknya pada pemecahan

${ }_{19}$ Reivich, Karen \& Andrew, Shatte, The Recilience Factor, (New York: Broadway Books, 2012), h. 31

${ }^{20}$ Reivich, Karen \& Andrew, Shatte, The Recilience Factor, (New York: Broadway Books, 2012), h. 32 
masalah difokuskan dan dipegang kendali oleh mereka, dengan perlahan mereka mulai menangani permasalahan yang ada, mengarahkan hidup mereka, bangkit serta mencapai kesuksesan.

e. Empathy

Empati erat sekali kaitannya dengan kemampuan individu dalam membaca tanda-tanda kondisi emosional dan psikologis seseorang. ${ }^{21}$ Kemampuan yang cukup mahir dalam menginterpretasikan bahasa-bahasa nonverbal yang dimiliki individu yang dapat ditunjukkan oleh orang lain, seperti ekspresi mimik muka, intonasi nada, bahasa tubuh dan dapat menangkap apa yang telah terpikirkan dan dirasakan orang lain. Oleh karenanya, seseorang yang dapat berempati cenderung memiliki hubungan sosial yang positif.

Tidak mampunya berempati dapat menyebabkan hubungan sosial yang sulit. $^{22}$ Individu-individu yang tidak membangun kemampuan untuk peka terhadap tanda-tanda nonverbal tidak dapat menempatkan dirinya dalam posisi orang lain, merasakan apa yang dirasakan orang lain dan memperkirakan maksud dari orang lain. Individu yang tidak mampu membaca tanda-tanda nonverbal orang lain sangat merugikan, baik dalam konteks hubungan kerja maupun hubungan personal, ini disebabkan untuk memahami dan menghargai kebutuhan dasar manusia. Individu dengan empati rendah cenderung mengulang pola yang dilakukan oleh individu yang tidak resilien, yaitu menyamaratakan semua keinginan dan emosi orang lain.

f. Self-efficacy

Self-efficacy merupakan hasil solusi masalah yang berhasil. Self-efficacy merepresentasikan keyakinan bahwa masalah yang kita alami dapat dipecahkan dan mencapai kesuksesan. Self-efficacy adalah hal yang penting untuk mencapai resiliensi.

Self-efficacy adalah faktor kognitif yang menentukan sikap dan perilaku seseorang pada permasalahan. Pada teori belajar sosial, dijelaskan Bandura bahwa faktor kognitif individu sangat menentukan perilaku seseorang. Bandura menolak pandangan behavioris dan psikoanalis yang sangat deterministik. Dengan self-efficacy tinggi, maka berbagai usaha dilakukan individu dalam menyelesaikan permasalahan. Keyakinan akan mampu menyelesaikan masalah, individu mampu mencari penyelesaian masalah dari peramasalahan yang ada, pantang menyerah terhadap kesulitan.

g. Reaching out

${ }^{21}$ Reivich, Karen \& Andrew, Shatte, The Recilience Factor, (New York: Broadway Books, 2012), h. 33

${ }^{22}$ Reivich, Karen \& Andrew, Shatte, The Recilience Factor, (New York: Broadway Books, 2012), h. 34 
Sebagaimana yang dijelaskan sebelumnya, bahwa resiliensi lebih dari sekedar bagaimana individu mampu mengatasi kemalangan dan bangkit dari keterpurukan, tapi lebih dari itu resiliensi merupakan kemampuan individu meraih aspek positif dari kehidupan setelah tertimpa kemalangan. Banyak individu tidak dapat melakukan reaching out, ini disebabkan mereka diajarkan sejak kecil untuk sedapat mungkin menghindari kegagalan dan situasi yang memalukan. Mereka adalah individu-individu yang lebih memilih memiliki kehidupan standar dibandingkan harus meraih kesuksesan tetapi harus berhadapan dengan resiko kegagalan hidup dan hinaan masyarakat. Ini menunjukkan kecenderungan individu untuk berlebih-lebihan (overestimate) dalam memandang kemungkinan hal-hal buruk yang dapat terjadi di masa mendatang. Individu-individu ini memiliki rasa ketakutan dalam memaksimalkan kemampuan mereka sampai batas akhir.

\section{Hakikat Inventori}

Inventori diartikan sebagai kumpulan pernyataan-pernyataan atau pertanyaan-pertanyaan yang sengaja dirancang untuk mengukur kepribadian, minat, sikap, aktivitas sosial, perilaku dan sebagainya serta responden menjawab sesuai petunjuk. ${ }^{23}$ Inventori juga diartikan sebagai alat pengukuran untuk ketrampilan-ketrampilan dan kebiasaan-kebiasaan untuk orang yangbelajar (Ikhsan : 1992). Belajarbukan hanya tentang pelajaran bidang studi, tetapi belajar mengenai ketrampilan-ketrampilan hidup, seperti memecahkan masalah, membuat keputusan, ketrampilan sosial dan lain sebagainya.

Keunggulan Inventori yaitu mengetahui karakteristik individu di berbagai aspek, salah satunya yakni resiliensi . Inventori sebagai alat pengumpul data obyektif, efektif dan efisien untuk mengungkap persepsi individu tentang dirinya melalui memilih pernyataanyang telah disesuaikan dengan karakteristik individu dibanding melalui wawancara langsung.

Keabsahan inventori diperoleh jika individu yang bersangkutanmemang mengisi item pernyataan sesuai dengan keadaan dirinya, dengan demikian inventori dapat memberimanfaat untuk individu dalam memahami dirinya dan terbuka pada pengalaman yang menunjang perkembangan dirinya secara optimal. Hasil inventori yang diperoleh bermanfaat bagi konselor untuk mendiagnosisaspek resiliensi mahasiswa yang terkait dengan ketepatan layanan bimbingan yang diberikan konselor.

Inventori Resiliensi

Inventori resiliensi adalah daftar pernyataan yang dirancang untuk mengetahui tingkat kemampuan seseorang untuk bertahan dalam keadaan yang

${ }^{23} \mathrm{~J}$ Lee, Cronbach, Essentials of Psychological Testing. Third Edition, (USA. Harper \& Row Publisher, 1949), h. 194 
sulit, berusaha belajar dan beradaptasi dengan keadaan tersebut serta bangkit dari keterpurukan untuk menjadi lebih baik. Inventori ini berisi sejumlah itemitem pernyataan dan sejumlah alternatif jawaban yang dikategorikan dalam skala.

Skala pengukuran resiliensi berdasar pada asumsi bahwa secara teoritis inventori ini tidak menguji responden dengan "benar-salah" atau "baik-tidak baik" (jawaban kualitatif). Tetapi lebih ditekankan pada jawaban berdasarkanketerangan yang sesuai dengan kondisi/situasi masing-masing individu.

\section{Penutup}

Inventori Resiliensi sangat mudah untuk digunakan karena terdapat petunjuk yang jelas dalam pengerjaanya. Berdasarkan penilaian ahli isi dari inventori Resiliensi yang dikembangkan telah sesuai dengan kondisi Mahasiswa Bimbingan dan Konseling Islam IAIN Tulungagung. Berdasarkan uji kelompok kecil menunjukan bahwa inventori Resiliensi diterima baik oleh mahasiswa. Inventori Resiliensi memiliki keterbatasan dan kelemahan yang masih memerlukan perbaikan dan pengembangan selanjutnya. Berdasarkan kesimpulan tersebut diharapkan dapat dijadikan masukan bagi peneliti selanjutnya untuk menyempurnakan produk yang telah dikembangkan. Sedangkan kelemahan dari pengembangan inventori resiliensi ini adalah:Pengembangan inventori Resiliensi memiliki keterbatasan dan kelemahan. Inventori Resiliensi hanya terbatas pada bantuan untuk mengukur tingkat Resiliensi mahasiswa saja dan tidak dapat digunakan membantu meningkatkan tingkat Resiliensi mahasiswa.

Perlu dikembangkan paket pelatihan atau media bimbingan untuk membantu mahasiswa dalam meningkatkan resiliensi-nya, mengingat Resiliensi merupakan sesuatu yang masih dapat dikembangkan, seperti yang telah dijelaskan sebelumnya. Kelemahan dari inventori Resiliensi ini adalah masih berbentuk teks biasa, sebaiknya untuk lebih lanjut bisa dikembangkan berbentuk aplikasi yang bisa dimasukan dalam android dan di download melalui Play Store sehingga akan lebih memudahkan prosesnya. Penilaian inventori Resiliensi ini hanya dilaksanakan sampai tahap uji ahli, uji coba produk awal, uji calon pengguna produk dan uji kelompok kecil karena keterbatasan waktu, sehingga masih ada yang beberapa yang belum sempurna dalam inventori Resiliensi ini.

\section{Bibliografi}

Ana Setyowati, dkk. 2010. Hubungan Antara Kecerdasan Emosional Dengan Resiliensi Pada Siswa Penghuni Rumah Damai, Jurnal Psikologi Undip Vol. 7, No. 1, April 2010

Akbar, Z., \& Pratasiwi R. 2017.Resiliensi Diri Dan Stres Kerja PadaGuru Sekolah Dasar, Jurnal Penelitian dan Pengukuran Psikologi Vol. 06, No. 2, Oktober 2017 
Borg, W. R. and Gall, M. D. 1983. Education Research.Longman Inc. 95 Street, White Plains

Brooks, Jean. 2016. Journal Strengthening Resilience in Children and Youths: Maximizing Opportunities through the Schools. Journal of Children \& Schools 28. Â2): 69-76.

Cronbach, J Lee. 1949. Essentials of Psychological Testing. Third Edition. USA. Harper \& Row Publisher

Galinsky, Ellen. 2010. Mind In The Making. New York: HarperCollins Publisher

Greeff, Annie. 2005. Resilience: Social Skills for Effective Learning vol.2. USA: Crown house publishing company

Gregory, R.J. 2000. Psychological Testing, Bab 3, Hal 95-137. Boston: Allan \& Bacon.

Grotberg, Henderson. 1999. Tapping Your Inner Strength How To Find The Recilience To Deal With Anything. Canada: New Harbinger Publications, Inc.

Henley, Robert. 2010. Resilience enhancing psychosocial programmes for youth in different cultural contexts: Evaluation and research. Journal of Progress in Development Studies 10, 4 (2010) pp. 295-307

Klohnen, E.C. 2010. Conseptual Analysis and Measurement of The Construct of Ego Resilience. Journal of Personality and Social Psychology, Volume. 70 No 5, p 1067-1079.

Mohaupt, Sarah. 2018. Review Article: Resilience and Social Exclusion. Journal of Social Policy \& Society 8:1, 63-71

Neenan, Michael. 2009. Developing Resilience a Cognitive Behavioral Approach. New York : Routledge

Reich, John. W. et.al. 2010. Handbook Of Adult Resilience. New York: A Division of Guilford Publications

Reivich, Karen \& Andrew, Shatte. 2012. The Recilience Factor. New York: Broadway Books

Santrock, John. W. 2010. Life-span development 13th edition. New York : McGraw-Hill

Sisca, Hyu,dkk. 2008. Resiliensi Perempuan Dewasa Muda Yang Pernah Mengalami Kekerasan Seksual Di Masa Kanak-Kanak, JurnalFakultas Psikologi Universitas Kristen Krida Wacan, Volume 2, no 1 
16 | ISLAMIC COUNSELING: Jurnal Bimbingan dan Konseling Islam, vol. 3, no. 1, 2019

Uyanto, Stanislaus. S. 2016. Pedoman Analisa Data dengan SPSS (edisi revisi). Yogyakarta: Stanislaus 